\title{
Mericarp micromorphology and anatomy of Salvia hedgeana Dönmez, S. huberi Hedge and S. rosifolia Sm. (section Salvia Hedge, Lamiaceae)
}

\author{
Hatice N. BüyüKkartaL ${ }^{1}$, Ahmet Kahraman ${ }^{2}, *$, Hatice ÇÖlgeÇEN ${ }^{3}$, \\ MuSA DOĞAN $^{2}$, ERSIN KARABACAK ${ }^{4}$ \\ ${ }^{1}$ Ankara University, Department of Biology, 06100 Ankara, Turkey. \\ ${ }^{2}$ Middle East Technical University, Department of Biological Sciences, \\ 06531 Çankaya, Ankara, Turkey. \\ ${ }^{3}$ Zonguldak Karaelmas University, Department of Biology, \\ 67100 Zonguldak, Turkey. \\ ${ }^{4}$ Çanakkale Onsekiz Mart University, Department of Biology, \\ 17020 Çanakkale, Turkey
}

\begin{abstract}
Mericarp (nutlet) micromorphology and pericarp structure of three morphologically similar endemic Salvia species; Salvia hedgeana, S. huberi and S. rosifolia were investigated using LM, SEM and TEM. Salvia hedgeana has larger mericarps and abscission scars than S. huberi and S. rosifolia. Mericarp length to width ratio ranges from 1.11 in $S$. hedgeana to 1.60 in $S$. huberi. Mericarp shape is mainly ovoid, rarely broadly ovoid in $S$. hedgeana, and oblong in S. huberi. The mericarp surface sculpturing pattern in all species is colliculate. However, exocarp cells are pentangular-hexangular in S. hedgeana, irregular in S. huberi and rounded and smaller in S. rosifolia. In Salvia huberi anticlinal walls are undulate whereas in S. hedgeana and S. rosifolia anticlinal walls are straight. Salvia hedgeana was distinguished from the others by the thickest pericarp $(146-185 \mu \mathrm{m})$. The sclerenchymatous region significantly varied between the species. It was 84-99 $\mu \mathrm{m}$ in $S$. hedgeana, 56-82 $\mu \mathrm{m}$ in $S$. huberi and 27-61 $\mu \mathrm{m}$ in S. rosifolia. The mesocarp was also thicker in S. hedgeana. The wetted mericarps produced mucilage, but $S$. huberi differed from the others in having translucent-milky white opaque mucilage with fibres or radiating cordons.
\end{abstract}

Keywords: Mericarp, micromorphology, anatomy, Salvia hedgeana, Salvia huberi, Salvia rosifolia, Lamiacaeae, SEM, TEM

\footnotetext{
* Corresponding author: e-mail: ahmetk@metu.edu.tr

Copyright $^{\circledR} 2011$ by Acta Botanica Croatica, the Faculty of Science, University of Zagreb. All rights reserved.
} 


\section{Introduction}

Lamiaceae (the mint family) has a cosmopolitan distribution represented by nearly 7200 species belonging to 236 genera, including many well-known plants, herbs, shrubs and trees of horticultural, economic and medicinal significance (HARLEY et al. 2004). It is the third largest family in Turkey with 45 genera and 574 species, 256 of which are endemic. The rate of endemism is $44.5 \%$ in this family (DAVIS 1965-1985, DAVIS et al. 1988, GÜNER et al. 2000).

Some mericarp (nutlet) characters can be used successfully at many taxonomic levels, depending on the characters chosen and the variation present (GUERIN 2005). Studies on mericarp micromorphology and pericarp anatomy in the family have proved the usefulness of these characters for species and generic level in the family Lamiaceae (WAGNER 1914; ISLEY 1947; WoJCIECHOWSKA 1958, 1961, 1966, 1972; HEDGE and LAMOND 1968; HUSAIN et al. 1990; REJDALi 1990; RYDING 1992, 1995, 2001, 2010; MARIN et al. 1994; TURNER and DelPRETE 1996; BudANTSEV and LoBOva 1997; Zhou et al. 1997; Duletić-LAUŠEVIC and MArin 1999; Mosquero et al. 2002; Guerin 2005; MoOn and Hong 2006; KAYA and Dímenci 2008; SALMAKI et al. 2008). IsLEY (1947) distinguished the tribes Ajugaea, Scutellarieae and Stachyeae in USA based on mericarp characters. WoJCIECHOWSKA (1966) investigated mericarp morphology including in some genera of Lamiaceae and pointed out that there were often important differences at both generic and species level. RYDING (1995) showed that the groups of Prunella and Cleonia plus Lepechinia and Chaunostoma were distinguishable from other labiates by differences in pericarp structure. BUDANTSEV and LoBova (1997) divided the subtribe Nepetinae (as tribe Nepeteae) into three informal generic groups based on differences in pericarp structure and other characters. WOJCIECHOWSKA (1966) and Moon and Hong (2006) pointed out that the genus Lycopus had a pericarp anatomy and mericarp morphology unique in the shape of corky crests and corky ring and the distribution of glandular trichomes, which were well distinguishable from the other genera in the tribe Mentheae. Moon and HoNG (2006) also found that mericarp morphological and anatomical characters of Lycopus were useful as diagnostic characters at the specific and interspecific levels.

Salvia L., the largest genus of the family Lamiaceae, is represented by about 1000 species. It is distributed extensively in tropical and temperate areas of the Old and New World, with three distinct regions of population: Central and South America (500 spp.), Western Asia (200 spp.) and Eastern Asia (100 spp.) (WALKER and SytSMA 2007). Based on the most recent classification (HARLEY et al. 2004), Lamiaceae is divided into seven subfamilies and the large subfamily Nepetoideae is divided into the three tribes Elsholtzieae, Mentheae and Ocimeae. Mentheae is divided into the three subtribes Salviinae, Menthinae and Nepetinae. However, the genera Melissa and Heterolamium are unclassified at this rank. According to their classification, the genus Salvia is classified into the subtribe Salviinae. Salvia species possess only two thecae on each stamen separated by an elongate connective while most Mentheae have four stamens (WALKER et al. 2004).

Mericarp micromorphology and anatomy are poorly reported in Salvia. In twenty Salvia species from Afghanistan, HEDGE (1970) reported that characters of myxocarpy (i.e. the production of mucilage when mericarps get in contact with water), thickness of the pericarp and the proportions of its individual layers as well as morphology of mericarps 
could be used in the systematics of the genus. Mericarp micromorphological characters of different Salvia species was investigated by MARIN et al. (1996) and ORAN (1997). They both pointed out that the variation in thickness of exocarp (=epicarp), mesocarp and endocarp morphology may be useful additional taxonomical markers.

In Turkey, there are 98 Salvia species reported (HEDGE (1982; KAHRAMAN et al. in press), 52 endemic species (53\%), divided into seven sections Salvia Hedge (syn. Eusphace Benth.), Aethiopis Benth., Plethiosphace Benth., Drymosphace Benth., Horminum Benth. and Hemisphace Benth. (BoIsSIER 1879, DoĞAN et al. 2007). Leaf (pinnatisect, trisect or simple), calyx (membranous or thick textured, upper lip 2-sulcate or not, concave or not), corolla (upper lip falcate or not, tube squamulate or not, annulate or not) and stamen (type A, B or C) characteristics are the most important means for distinguishing these sections. The section Salvia has usually pinnatisect leaves, thick-texture calyces, straight upper corolla lips, annulate corolla tubes and type A stamens with shorter staminal connectives than filaments and larger upper theca than the lower theca.

Salvia hedgeana Dönmez, S. huberi Hedge and S. rosifolia Sm. included in the section Salvia are endemic to Turkey. They show morphologically close similarities to each other (DönMEZ 2001), especially S. huberi and S. rosifolia (HEDGE 1982, personal observation). Salvia hedgeana is also close to $S$. caespitosa Montbret et Aucher ex Benth. in terms of its habit and distribution area. Even though micromorphological and anatomical studies can be used as a powerful tool in delimitation of species, there have been no mericarp micromorphological and anatomical studies on the species examined. This study aims to examine micromorphological and anatomical characteristics of mericarps of the three Salvia species which have not been studied to date; using light microscopy, scanning electron microscopy and transmission electron microscopy.

\section{Materials and methods}

Different populations of Salvia, Salvia hedgeana Dönmez, S. huberi Hedge and $S$. rosifolia $\mathrm{Sm}$. were investigated in localities presented in table 1 . The herbarium specimens were deposited in Department of Biological Sciences, Middle East Technical University, Ankara, Turkey and the Herbarium of Çanakkale Onsekiz Mart University.

\section{Light microscopy (LM)}

Mericarps were first examined using a stereomicroscope to ensure that they were of normal size and maturity. The ripe mericarps from each population were measured in order to determine the average mericarp size and abscission scar diameter. The pericarp structure of the mericarps was investigated from softened herbarium specimens. The mature mericarps were placed in distilled water for 24 hours, 3\% glutaraldehyde and then $\% 1$ osmium tetraoxide. The materials were dehydrated through a graduated ethanol series, embedded in Epon 812 (LUFT 1961), sectioned, stained with methylene blue and toluidine blue, and permanently mounted. These sections were examined for the pericarp features, and thickness of the pericarp and mesocarp, sclerenchymatous region, endocarp, size of crystals and mucilaginous cells were measured and photographed under LM. 
BüyüKkartal H. N., Kahraman A., ÇölgeçEn H., DoĞan M., Karabacak E.

Tab. 1. List of the studied populations of Salvia hedgeana, S. huberi and S. rosifolia.

\begin{tabular}{|c|c|c|}
\hline Species & Collection data & Collection number \\
\hline \multirow[t]{2}{*}{ S. hedgeana } & $\begin{array}{l}\text { B7 Sivas: Divriği, Karasar Pass, Uzunkaya to Kayaburun, } \\
1450 \text { m, steppe, 25.vii. } 2008\end{array}$ & A. Kahraman $1589 C^{a, b}$ \\
\hline & $\begin{array}{l}\text { B7 Sivas: Divriği, Karasar Pass, near Uzunkaya village, } \\
1460 \text { m, steppe, 9.vii.2006 }\end{array}$ & A. Kahraman $1255 \mathrm{~A}^{\mathrm{a}, \mathrm{c}}$ \\
\hline \multirow[t]{5}{*}{ S. huberi } & $\begin{array}{l}\text { A8 Bayburt: } 12 \mathrm{~km} \text { from Bayburt to Maden, } 1615 \mathrm{~m} \text {, } \\
\text { steppe and slopes, 12.vii. } 2006\end{array}$ & E. Karabacak $4979^{a}$ \\
\hline & $\begin{array}{l}\text { A8 Erzurum: } 41 \mathrm{~km} \text { from Erzurum to Tortum, } 2121 \mathrm{~m} \text {, } \\
\text { roadside slopes, 14.vii.2006 }\end{array}$ & A. Kahraman $1474^{\mathrm{a}, \mathrm{b}, \mathrm{c}}$ \\
\hline & A8 Erzurum: Tortum Waterfall, 1010 m, scrubs, 22.vi.2008 & E. Karabacak $6137^{\mathrm{a}}$ \\
\hline & $\begin{array}{l}\text { A8 Erzurum: Tortum, above Balikli village, } 1342 \mathrm{~m} \text {, } \\
\text { stony slopes, 22.vi. } 2008\end{array}$ & E. Karabacak $6144^{\mathrm{a}}$ \\
\hline & $\begin{array}{l}\text { A8 Erzurum: } 10 \mathrm{~km} \text { from Tortum to Yusufeli, } 1367 \mathrm{~m} \text {, } \\
\text { calcareous slopes and screes, 9.vii.2007 }\end{array}$ & E. Karabacak $5611^{\text {a }}$ \\
\hline \multirow[t]{5}{*}{ S. rosifolia } & $\begin{array}{l}\text { A8 Bayburt: Gümüşhane to Bayburt, Nişantaşı village, } \\
\text { Osluk (Korgan) bridge environs, } 1616 \text { m, steppe and } \\
\text { rocky slopes, 11.vii.2006 }\end{array}$ & E. Karabacak $4963^{\mathrm{a}}$ \\
\hline & $\begin{array}{l}\text { A9 Kars: } 22 \mathrm{~km} \text { from Kağızman to Kars, } 1581 \mathrm{~m} \text {, } \\
\text { roadside slopes, 13.vii.2007 }\end{array}$ & A. Kahraman $1470^{\mathrm{a}, \mathrm{c}}$ \\
\hline & $\begin{array}{l}\text { A9 Kars: } 28 \text { km from Kağızman to Kars, } 1819 \text { m, } \\
\text { roadside slopes, 29.vii.2008 }\end{array}$ & A. Kahraman $1607^{\mathrm{a}, \mathrm{b}}$ \\
\hline & $\begin{array}{l}\text { A9 Kars: Kağızman to Kars, near Kötek village, } 1642 \text { m, } \\
\text { screes, 8.vii. } 2007\end{array}$ & E. Karabacak $5585^{\mathrm{a}}$ \\
\hline & A9 Erzurum: Oltu, Çamlıdere, 1443 m, slopes, 22.vi.2008 & E. Karabacak $6161^{\text {a }}$ \\
\hline
\end{tabular}

${ }^{\mathrm{a}}$ Specimens used for morphological studies of mericarps by stereomicroscopy; ${ }^{\mathrm{b}}$ Specimens used for micromorphological studies of mericarps by SEM; ${ }^{\mathrm{c}}$ Specimens used for anatomical studies of mericarps by LM and TEM.

\section{Scanning Electron Microscopy (SEM)}

Mature mericarps were directly placed on aluminium stubs using double-sided adhesive tape, sputter coated with gold using a Hummer VII gold-coating apparatus, then viewed with JEOL-6060 SEM and photographed.

\section{Transmission Electron Microscopy (TEM)}

Ultrathin sections of the mericarps were stained with uranyl acetate (STEMPAK and WARD 1964) and lead citrate (SATO 1967), then examined with JEOLL CX-100 TEM and photographed.

Each quantitative character was analyzed for its mean and median values, range, standard deviation and significance, using the Statistica version 9 software. Significance of differences was tested using one-way ANOVA and Tukey's honestly significant difference 
(HSD) test. The terminology was adjusted for mericarp surface sculpturing (STEARN 1992, SALMAKI et al. 2008) and for pericarp structure (HEDGE 1970, RYDING 2010).

To determine for the absence or presence of myxocarpy, we treated with distilled water ten mericarps from each species examined, following RYDING (1992). Mucilage characteristics regarding colour, consistency and general appearance were followed according to HEDGE (1970).

\section{Results}

The significance of differences in basic parameters defines each species (Fig. 1, Tab. 2). Three characters such as mericarp width, pericarp thickness and sclerenchymatous region thickness allow clear discrimination of the three species. Mericarp length/width ratio helps to separate Salvia huberi from $S$. hedgeana and S. rosifolia whereas size of exocarp cells distinguishes between $S$. rosifolia and $S$. hedgeana and $S$. huberi. Mericarp length, abscission scars and mesocarp thickness contribute the distinction between $S$. hedgeana and the remaining taxa. Nonetheless, some of these characters indicate to some degree overlapping values.

Among the studied qualitative characters of the species, shape of mericarp and exocarp cells and structure of anticlinal walls were found to be the most significant diagnostic characters (Tab. 3).

\section{Mericarp micromorphology}

Size of mericarps measured from different populations of the species varied from 2.46 $\mathrm{mm}$ (Salvia huberi) to $4.36 \mathrm{~mm}$ (S. hedgeana) in length and $1.83 \mathrm{~mm}$ (S. huberi) to 3.44 (S. hedgeana) in width. Shape of the mericarps was mainly ovoid, rarely broadly ovoid as in $S$. hedgeana or oblong as in $S$. huberi (Fig. 2). They ranged in length to width ratio from 1.11 (S. hedgeana) to 1.60 (S. huberi). When mericarps were not fully matured, their colour was greenish at first, and then turned to dark brown or blackish. Transverse sections of the mericarps were also rounded-trigonous. Abscission scars were almost spherical and their diameter ranged between $0.41 \mathrm{~mm}$ as in $S$. huberi and $0.83 \mathrm{~mm}$ as in $S$. hedgeana.

In the species examined, the mericarps were glabrous and the sculpturing pattern was of the colliculate type characterized by small hill-like eminences, spaced, covering throughout the mericarp surface. The colliculate sculpturing could be subdivided based on shape of exocarp cells: pentangular or hexangular in $S$. hedgeana (Fig. 3A), irregular in S. huberi (Figs. 3C-D) and rounded in S. rosifolia (Figs. 3E-F). Size of these cells varied from 7.45 $\mu \mathrm{m}$ as in $S$. rosifolia to $27.79 \mu \mathrm{m}$ as in $S$. huberi. Striation partially occurred on their surface (Fig. 3B). Anticlinal walls were represented by straight channels in $S$. hedgeana and $S$. rosifolia or undulate channels in $S$. huberi. Outer periclinal walls were convex, but also consisted of small holes in S. huberi (Figs. 3C-D).

\section{Mericarp anatomy}

The LM and TEM investigation revealed a pericarp differentiated into four main regions: the exocarp (outer epidermis), mesocarp, sclerenchyma region and endocarp (inner epidermis) (Figs. 4A, C, F). The outermost region was the exocarp, consisting of a single layer of parenchymatous cells. These cells were differentiated into two types: large oblong or oval mucilaginous cells in groups of one or more and narrow non-mucilaginous cells 
BüyüKkartal H. N., Kahraman A., ÇölgeÇen H., DoĞan M., Karabacak E.
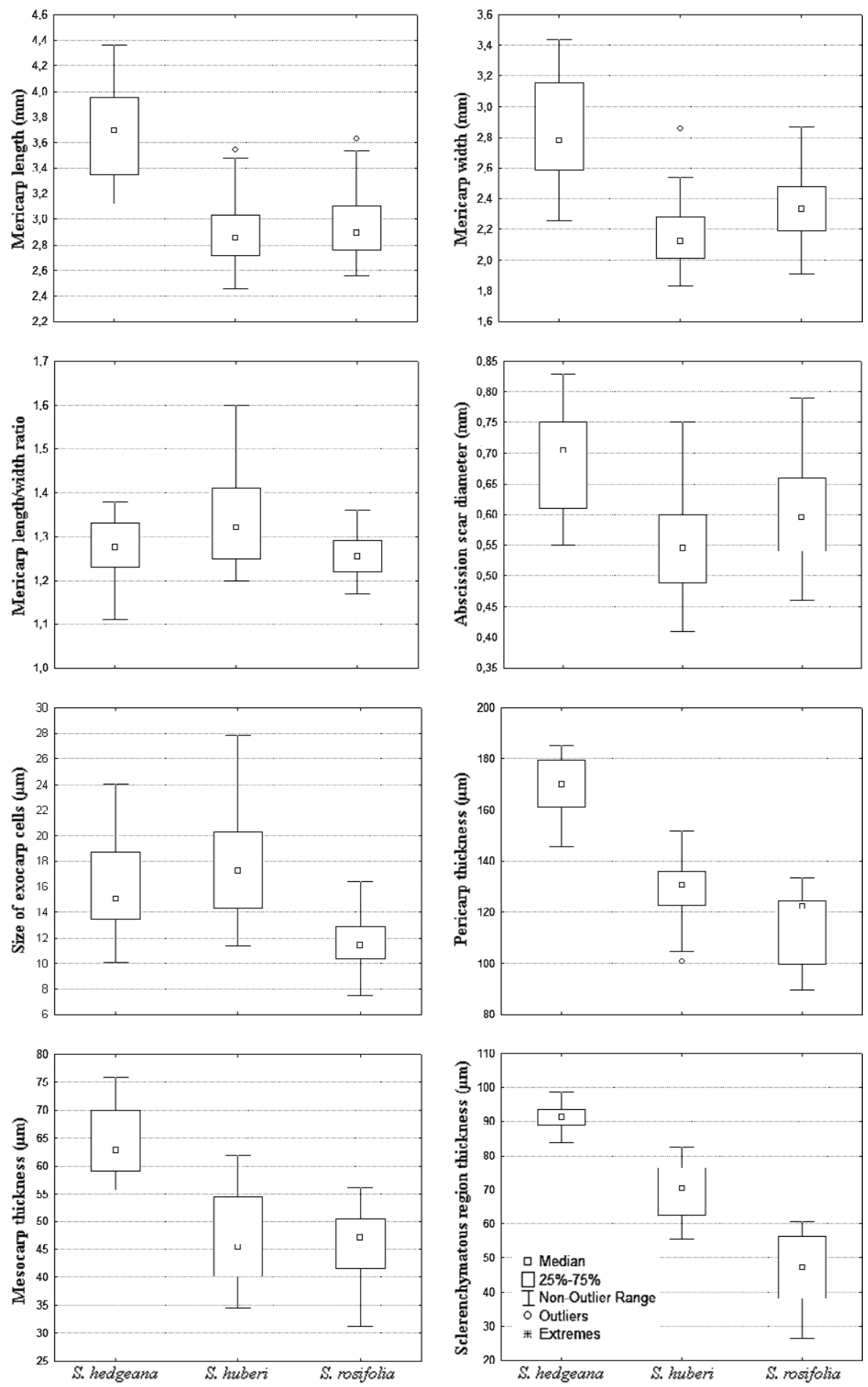

Fig. 1. Box plots of the main discriminant quantitative characters in Salvia species examined. 


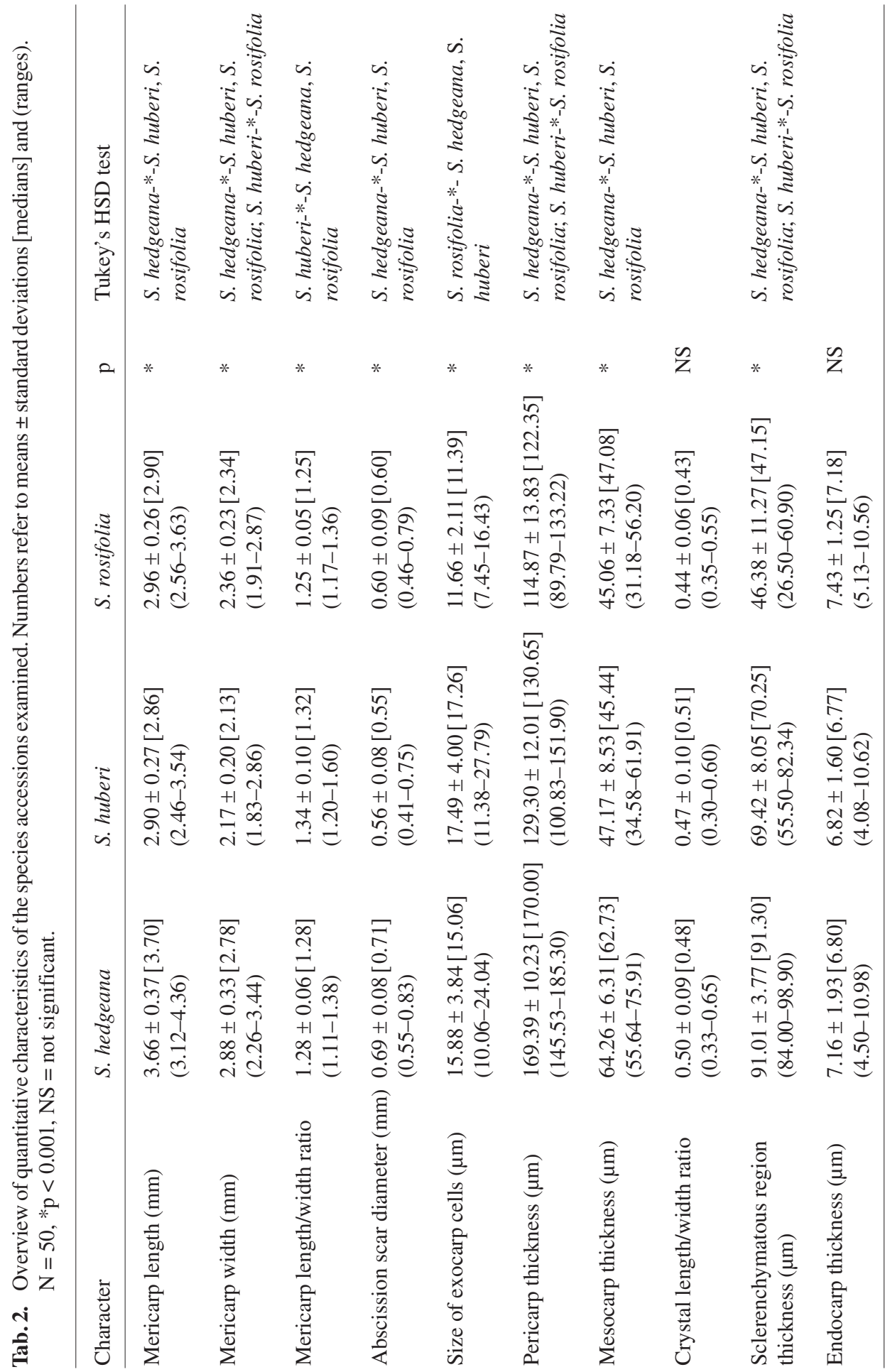


Tab. 3. Characteristics in Salvia examined.

\begin{tabular}{|c|c|c|c|}
\hline Character & S. hedgeana & S. huberi & S. rosifolia \\
\hline Mericarp shape & Ovoid to broadly ovoid & Ovoid to oblong & Ovoid \\
\hline $\begin{array}{l}\text { Mericarp transverse } \\
\text { section }\end{array}$ & Rounded-trigonous & Rounded-trigonous & Rounded-trigonous \\
\hline Mericarp colour & Mostly blackish & Mostly blackish & Mostly blackish \\
\hline Abscission scar shape & \pm spherical & \pm spherical & \pm spherical \\
\hline Surface sculpturing type & Colliculate & Colliculate & Colliculate \\
\hline Shape of exocarp cells & Pentangular-hexangular & Irregular & Rounded \\
\hline Anticlinal walls & $\begin{array}{l}\text { Represented by } \\
\text { straight channels }\end{array}$ & $\begin{array}{l}\text { Represented by } \\
\text { undulate channels }\end{array}$ & $\begin{array}{l}\text { Represented by } \\
\text { straight channels }\end{array}$ \\
\hline Periclinal walls & Convex & $\begin{array}{l}\text { Convex with small } \\
\text { holes }\end{array}$ & Convex \\
\hline
\end{tabular}
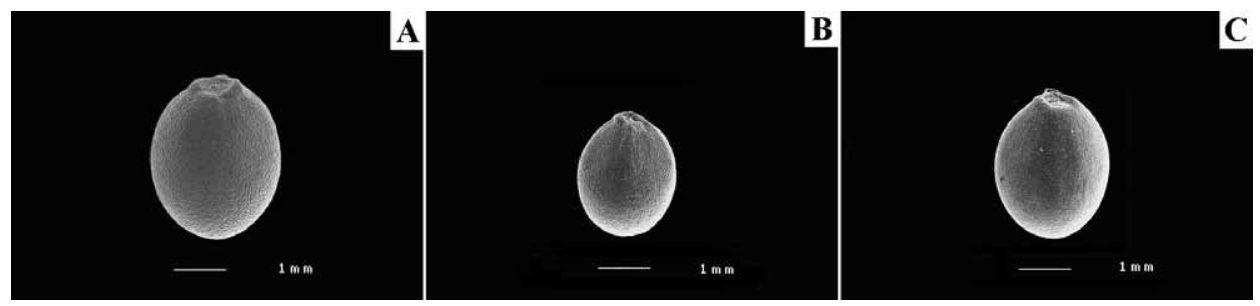

Fig. 2. SEM micrographs showing general appearance of mericarps in Salvia species examined. A - S. hedgeana, B - S. huberi, C-S. rosifolia.

with thin cavities, located between the former cells (Figs. 4A, C, D, F, G). The mucilaginous cells had thickened walls and their size was very variable within the same mericarp. Hence, we measured the pericarp thickness without the mucilaginous cells. It ranged from $89.79 \mu \mathrm{m}$ in $S$. rosifolia to $185.30 \mu \mathrm{m}$ in S. hedgeana. The mucilage pocket encircled the central cytoplasmic column with darkly staining mucilage (Figs. 5C, F).

Below the exocarp, there is the mesocarp region (31.18-75.91 $\mu$ m thick) composed of a dark amorphous mass of several strongly compressed and almost indistinguishable cells. This region contained several groups of sclerenchymatic cells with the luminar cavity enlarged (Figs. 4B, D). Brachysclereids (=stone cells) were characterized by thick walls (Figs. 4B, 5A, C, E). These cells accumulated tannins. The innermost layer of the mesocarp contained prismatic crystals (Figs. 4A, C, E, F). They were 6.67-13.22 long $\mu \mathrm{m}$ and $15.14-32.52 \mu \mathrm{m}$ wide. They varied in length to width ratio between 0.30 and 0.65 .

The mesocarp was followed by the sclerenchymatous region consisting of a layer of thick-walled macrosclereids, i.e. Malpighian cells (Figs. 4E, 5B, D) in which tannins accumulated (Fig. 5B). The sclerenchymatous region thickness varied between $26.50 \mu \mathrm{m}$ in $S$. rosifolia and $98.90 \mu \mathrm{m}$ thick in $S$. hedgeana, with small and rounded luminar cavities at or near the centre (Fig. 5). The thickness of the sclerenchymatous layer was nearly half of the total pericarp thickness. 

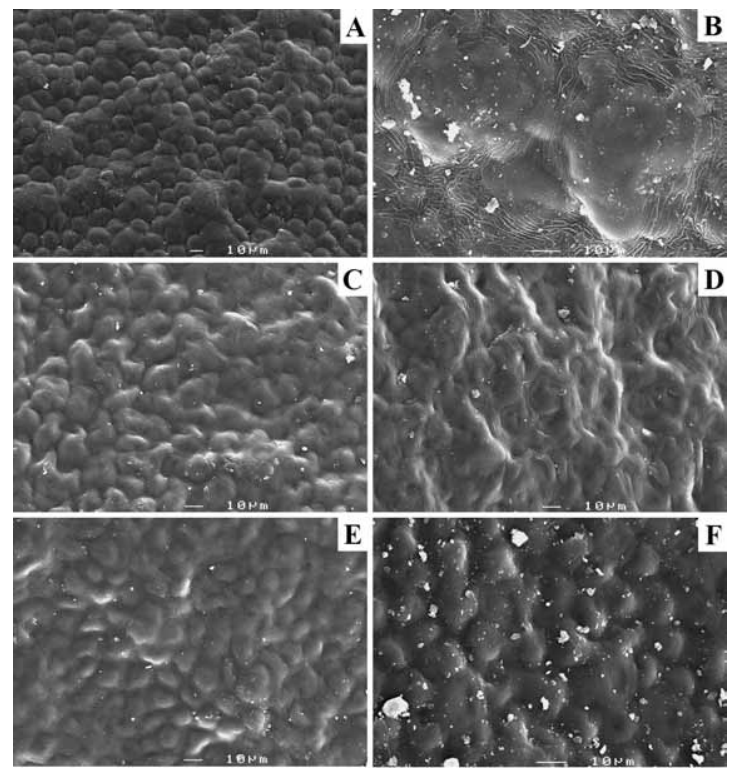

Fig. 3. SEM micrographs showing mericarp surface sculpturing in Salvia species examined. A-B S. hedgeana, C-D - S. huberi, E-F - S. rosifolia.

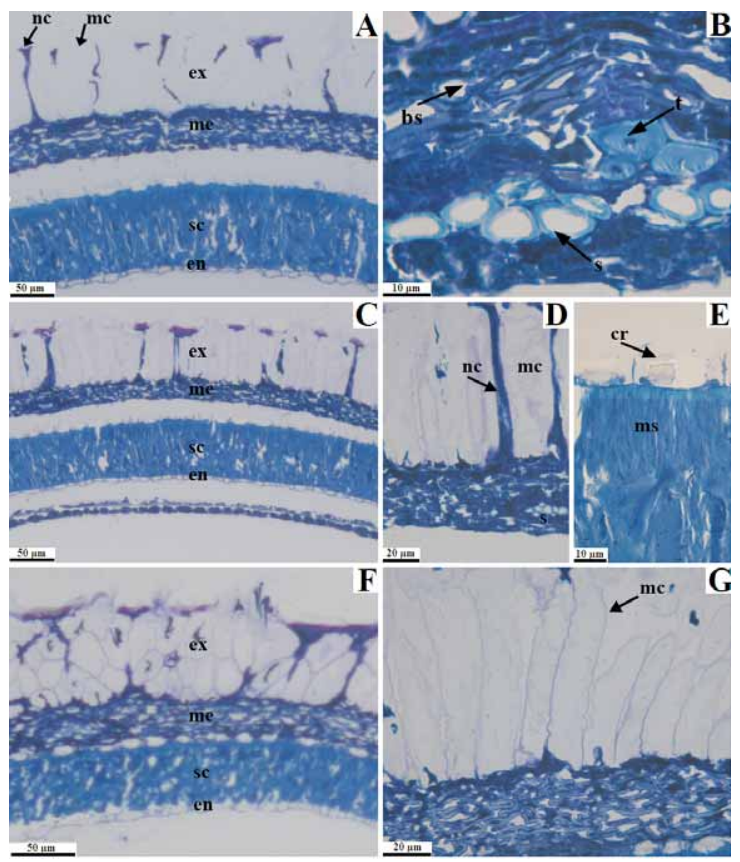

Fig. 4. LM micrographs showing pericarp structure of Salvia hedgeana (A-B), S. huberi (C-E) and S. rosifolia (F-G). bs - Brachysclerids, cr - crystals, ex - exocarp, en - endocarp, me mesocarp, $\mathbf{m c}$ - mucilaginous cells, $\mathbf{n c}$ - non-mucilaginous cells, $\mathbf{s}-$ sclerenhymatic cells, $\mathbf{s c}-$ sclerenchymatous region, $\mathbf{t}-$ tannins. 


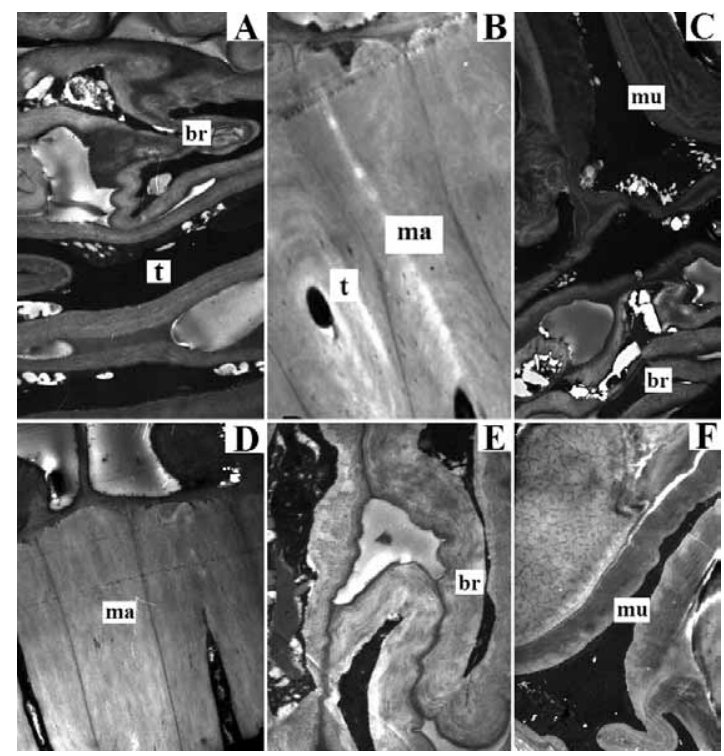

Fig. 5. TEM micrographs showing cells in pericarps of $S$. hedgeana with brachysclereids and tannins in the mesocarp (A), S. hedgeana with macrosclereids and tannins in the sclerechymatous region (B), S. huberi with mucilaginous cells in the exocarp and with brachysclereids in the mesocarp (C), S. huberi with macrosclereids in the sclerenchymatous region (D), S. rosifolia with brachysclereids in the mesocarp $(\mathbf{E})$, and S. rosifolia with mucilaginous cells in the exocarp (F). br-brachysclereids, ma-macrosclereids, mu-mucilaginous cells, $\mathbf{t}$ - tannins.

The endocarp, consisting of a single layer of transversely arranged cells, was 4.08$10.98 \mu \mathrm{m}$ thick (Figs. 4A, C, F).

A mucilage reaction (myxocarpy) was seen in the wetted mericarps of the studied species. In S. huberi and S. rosifolia mucilage was formed after the first half hour of wetting, but in $S$. hedgeana the time taken was longer than one hour. According to colour, consistency and degree of transparency, two mucilage types were observed: transparent and fibreless or having radiating cordons embraced by the mass of mucilage, and translucent-milky white opaque with fibres or radiating cordons embraced by the mass of mucilage. The former type was observed in S. hedgeana (Fig. 6A) and S. rosifolia (Fig. 6D) whereas the latter type was detected in $S$. huberi (Fig. 6B-C).

\section{Discussion}

The size, shape, length to width ratio, abscission scar diameter, size and shape of exocarp cells and structure of anticlinal walls varied significantly in the investigated species (Tabs. 2, 3). Salvia hedgeana was easily distinguished from S. huberi and $S$. rosifolia by large mericarps and abscission scars. Their mericarps were ovoid, but $S$. huberi had also oblong mericarps. In addition, the mericarps ranged in their length to width ratio from 1.11 in $S$. hedgeana to $1.60 \mathrm{~S}$. huberi. HeDGE (1982) reported that some species of the Turkish Salvia had brown or black mericarps and rounded, trigonous or rounded-trigonous 


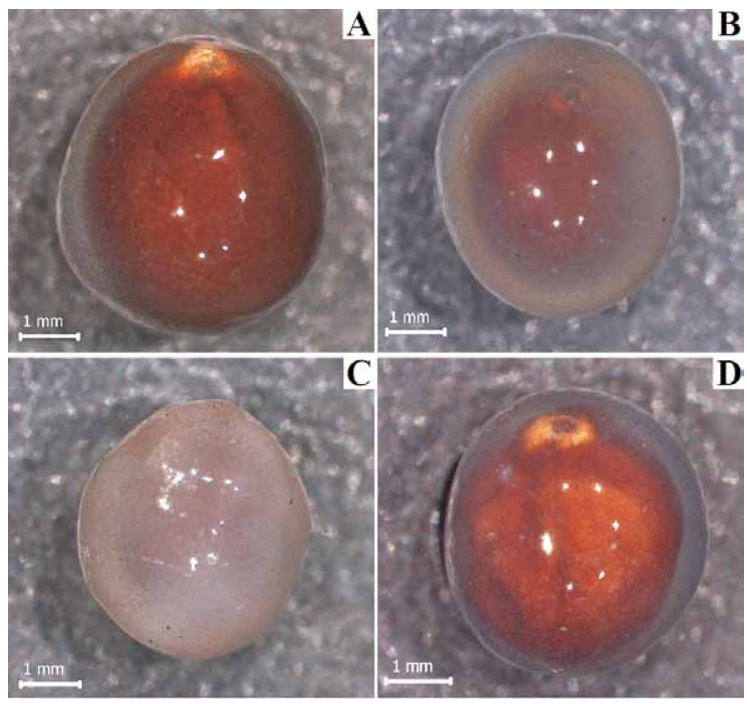

Fig. 6. Stereomicroscopic micrographs showing the mucilaginous reaction (myxocarpy) on mericarps in Salvia hedgeana (A), S. huberi (B-C), and S. rosifolia (D).

mericarps (the most common) in transverse sections. However, the investigated species had mericarps similar in colour, transverse sections, as well as, abscission scar shape. The abscission scar and mericarp shape were invariable in the tribe Saturejeae while these characters varied significantly in the Westringieae (HUSAIN et al. 1990).

The studied species showed a similar sculpturing pattern, but exocarp cells were pentangular-hexangular in $S$. hedgeana, irregular in $S$. huberi and rounded and smaller in $S$. rosifolia. While exocarp cells of $S$. huberi had undulate anticlinal walls, those of $S$. hedgeana and $S$. rosifolia had straight anticlinal walls. Small holes were also present on the outer periclinal walls of $S$. huberi. Though mericarp sculpturing was found to be useful for separating species within the sections in the genus Stachys, it did not seem to be a helpful character at the infrageneric level (SALMAKI et al. 2008). Mericarp shape, nature of the abscission scar, nature of surface sculpturing, exocarp cell shape and sculpturing, and nature of the indumentum were mainly useful for infrageneric delimitation in the genera Hemigenia and Microcorys (GUERIN 2005).

According to the mericarp anatomical properties of the species examined, the thickest pericarp was found in S. hedgeana, whereas S. rosifolia had the thinnest pericarp. Moreover, the thickness of the sclerenchymatous region significantly varied among the species. DULETIĆ-LAUŠEVIC and MARIN (1999) determined that the pericarp thickness in the tribe Nepetoideae of Lamiaceae was often correlated with dimensions of mericarps. However, they also indicated that the pericarps of Mentha aquatica mericarps were very thick (approximately $95 \mu \mathrm{m}$ ), even though the species had very small mericarps (nearly $0.8 \mathrm{~mm} \times$ $0.6 \mathrm{~mm}$ ). In our work, $S$. hedgeana had the largest mericarps that were composed of the thickest pericarp structure. In the mesocarp and sclerenchmatous region, tannins were recognized. They were thought to protect the plant against dehydration, rotting and damage by predators such as animals and insects (FAHN 1990). 
Mericarp data are not only useful as a diagnostic character in delimitation of the species of Salvia, but also they provide support for separating sections of the genus as indicated by some early researchers (WOJCIECHOWSKA 1966, MARIN et al. 1994, ÖZKAN et al. 2009). According to data presented in the Flora of Turkey (HEDGE 1982), members of the sections Plethiosphace and Hemisphace can be distinguished from those of the other sections by their smaller mericarps. Mericarp size of the section Plethiosphace is 1.5-2.5 $\times 1.0-2.0$ $\mathrm{mm}$ and mericarp size of the section Hemisphace is $2.2-2.5 \times 1.3-1.5 \mathrm{~mm}$. In MARIN et al. (1996), mericarps of S. officinalis L. (sect. Salvia) and S. glutinosa L. (sect. Drymosphace) have convex anticlinal walls and concave periclinal walls in the exocarp cells. However, those of $S$. officinalis exhibit the isodiametric hexagonal or pentagonal exocarp cells while the mericarps of $S$. glutinosa L. have smaller exocarp cells, which are not clearly angular. Moreover, Salvia coccinea Juss. ex Murr. and S. splendens Ker-Gawl. in subgenus Calosphace are particularly distinguished from all other species by regular pentangular or hexangular exocarp cells with convex periclinal walls. SEM images of S. coccinea presented by the authors seem to be very similar to those of $S$. hedgeana in our study. $S$. ballsiana and S. macrochlamys in the section Salvia studied by KAHRAMAN et al. (2010a, b) have a surface sculpturing similar to that of $S$. hedgeana, but $S$. ballsiana $(4.5-5.3 \times$ $3.8-4.2 \mathrm{~mm})$ and $S$. macrochlamys $(4.7-5.2 \times 3.8-4.1 \mathrm{~mm})$ have larger mericaps. $S$. verticillata in the section Hemisphace had an irreegular, reticulate surface pattern with exocarp cells of varying size (MARIN 1996). ÖZKAN et al. (2009) reported mericarp properties of 12 Turkish Salvia taxa belonging to different sections. They grouped the species into three types of sculpturing: foveate, reticulate and verrucate. The three types were observed in the section Aethiopis among the examined taxa. While the studied taxa of the sections Salvia and Hymenosphace had the foveate sculpturing pattern, those of the sections Hemisphace and Plethiosphace had verrucate sculpturing pattern. In our study, the species belonging to sect. Salvia showed the colliculate pattern of mericarp sculpturing. Some discrepancies hamper the usefulness of direct comparisons with the findings of this previous study. In some cases, the SEM images of several taxa do not seem to correspond with surface sculpturing types assigned to the species. In some cases, the magnification seems to be insufficient to show the detail of the sculpturing patterns of exocarp cells.

Variation in thickness of the pericarp and its individual layers among species have been already indicated (ORAN 1997). The pericarp thickness in the investigated species ranged from $48 \mu \mathrm{m}$, as in S. viscosa (sect. Plethiosphace), to $275.5 \mu \mathrm{m}$, as in S. fruticosa (sect. Salvia). In our study, the species have pericarps varying between 89.79 and $185.30 \mu \mathrm{m}$ in thickness.) Two-staminate Salviinae (e.g. Salvia and Rosmarinus) could be distinguished from four-staminate Salviinae (e.g. Lepechinia and Chaunostoma) and other Mentheae by having large crystals in the innermost cell layer of the mesocarp (RYDING 2010). Except in a few of the species (e.g. Salvia splendens and Perouskia abrotanoides), crystals were observed in all the genera. The sclerenchymatous region varied between $32 \mu \mathrm{m}(S$. splendens and $S$. taraxacifolia) and $115 \mu \mathrm{m}$ (S. officinalis). S. officinalis was also found to differ from the other studied species in having a very much thicker sclerenchymatous region. The Salviinae with four stamens differed from the two-staminate $(3-9 \mu \mathrm{m})$ and other Mentheae $(2-12 \mu \mathrm{m})$ in having a thicker endocarp $(17-40 \mu \mathrm{m})$. Our findings confirmed data presented in the previous study. Prismatic crystals were detected in the mesocarp of the species studied. The thickness of the sclerenchymatous region was measured between $26.50 \mu \mathrm{m}$ in S. rosifolia and $98.90 \mu \mathrm{m}$ in $S$. hedgeana. The endocarp thickness ranged from $4.08 \mu \mathrm{m}$ to $10.98 \mu \mathrm{m}$. 
Myxocarpy, the production of mucilage by wetted mericarps, is widespread in the subfamily Nepetoideae (WAGNER 1914; HedGe 1970; SwArbrick 1971; WitZTUM 1978; RYding 1992, 2001, 2010; DuletiĆ-LAUŠEVIC and MARIN 1999; HARLEY et al. 2004). Morphologically allied species had similar mucilage properties (HEDGE 1970). In this study, we observed that the species did produce mucilage on their mericarp surfaces, but $S$. huberi seemed to differ from the others in colour, consistency and degree of transparency. In a total of over forty Salvia species investigated in Southwest Asia, only three failed to produce mucilage on the mericarp surface (HedGE 1970). All the Salvia species known from Afghanistan had mucilage formation, with one exception (HEDGE 1970). These mucilage-producing species were grouped into four basic types according to their mucilage characteristics: transparent, translucent, milky opaque and brownish opaque. The occurrence of mucilage was found in 14 Salvia species in Jordan which had not been previously examined (Oran 1997). However, one species, S. napifolia (sect. Hemisphace), only sometimes produced a very small amount or no visible mucilage. The greatest mucilage production was detected in S. viridis (sect. Horminum). There was no mucilage on the mericarp surface of all the taxa studied in Lycopus, but a moderately strong mucilaginous reaction was seen in Elsholtzia blanda Benth. in the tribe Elsholtzieae (MoON and HoNG 2006).

Mucilage plays a significant role in anchoring the mericarp to the soil. Presence or absence of mucilage seems to be a very homoplastic character in Nepetoideae; most of the species-rich genera and many of the genera with few species contained myxocarpic as well as non-myxocarpic species (RYDING 1992). Therefore, the amount of mucilage may evolve quickly in order to adapt the species to different biological conditions. Even though the presence of mucilage may provide a considerable selective advantage under certain conditions, the production of mucilage may be costly for the plants, and it may be quickly lost where it has no function. Plants growing in moist habitats more often had non-mucilaginous mericarps (RYDING 1992, 2001). The whole of Lycopus species grow in low wet places and have non-mucilaginous mericarps (MoON and Hong 2006). The species of Salvia examined grow in dry habitats and have mucilaginous mericarps.

Mericarp micromorphological and anatomical characteristics might be helpful in the identification of the species studied. Nevertheless, the value of these characteristics can be better appreciated by examining other species of Salvia.

\section{Acknowledgements}

The authors thank the Scientific and Technical Research Council of Turkey for the financial assistance (TuBíTAK-TBAG-104 T 450) and Çanakkale Onsekiz Mart University Research Fund (2007/14).

\section{References}

BoIsSIER, E. P., 1879: Flora Orientalis. Genevae et Basileae.

Budantsev, A. V., Lobova, T. A., 1997: Fruit morphology, anatomy and taxonomy of tribe Nepeteae (Labiatae). Edinburgh Journal of Botany 54, 183-216 
DaVIS, P. H., 1965-1985: Flora of Turkey and the east Aegean islands, 1-9. Edinburgh University Press, Edinburgh.

Davis, P. H., Mill, R. R., TAN, K., 1988: Flora of Turkey and the east Aegean islands, 10 (First Supplement). Edinburg University Press, Edinburg.

Doğan, M., Akaydin, G., Celep, F., Bagherpour, S., Kahraman, A., Karabacak, E., 2007: Infrageneric delimitation of Salvia L. (Labiatae) in Turkey. Proceedings 7 International Symposium on plant life of southwest Asia, Eskişehir, 1-12.

Dönmez, A., 2001: A new Turkish species of Salvia L. (Lamiaceae). Botanical Journal of the Linnean Society 137, 413-416.

Duletić-LaušEvic, S., Marin, P. D., 1999: Pericarp structure and myxocarpy in selected genera of Nepetoideae (Lamiaceae). Nordic Journal of Botany 19, 435-446.

FAHN, A., 1990. Plant anatomy. Pergamon, Oxford.

GuERIN, G. R., 2005: Nutlet morphology in Hemigenia R. Br. Microcorys R. Br. (Lamiaceae). Plant Systematics and Evolution 254, 49-68.

Güner, A., Özhatay, N., Ekim, T., BAŞER, K. H. C., 2000: Flora of Turkey and the east Aegean islands 11 (Second Supplement). Edinburgh University Press, Edinburgh.

Harley, R. M., Atkins, S., Budantsev, A. L., Cantino, P. D., Conn, B. J., Grayer, R., Harley, M. M., De Kok, R., Krestovskaja, T., Morales, R., Paton A. J., Ryding, O., Upson, T., 2004: Labiatae. In: KADEREIT, J. W. (ed.), The families and genera of vascular plants 7, Lamiales, 167-275. Springer-Verlag, Berlin.

Hedge, I. C., Lamond, J., 1968: Studies in the flora of Afghanistan: 7, Labiatae. Notes from the Royal Botanic Garden 28, 97-123.

Hedge, I. C., 1970: Observations on the mucilage of Salvia fruits. Notes from the Royal Botanic Garden Edinburgh 30, 79-95.

Hedge, I. C., 1982: Flora of Turkey and the east Aegean islands. In: DAVIs, P.H. (ed.), Salvia L., 7, 400-461. Edinburgh University Press, Edinburgh.

Husain, S. Z., Marin, P. D., ŠIlić, C, QAiser, M., PetKović, B., 1990: A micromorphological study of some representative genera in the tribe Satureae (Lamiaceae). Botanical Journal of the Linnean Society 103, 59-80.

ISLEY, D., 1947: Investigations in seed classification by family characteristics. Iowa Agricultural Experimental University Journal of Research 12, 247-260.

Kahraman, A., Dogan, M., Celep, F., Koyuncu, M., Akaydin, G., 2010a: Morphology, anatomy, palynology and nutlet micromorphology of the rediscovered Turkish endemic Salvia ballsiana (Lamiaceae) and their taxonomic implications. Nordic Journal of Botany 28, 91-99.

Kahraman, A., Celep, F., DoĞAn, M., 2010b: Morphology, anatomy, palynology and nutlet micromorphology of Salvia macrochlamys (Labiatae) in Turkey. Biologia 65, 219-227.

Kahraman, A., Dogan, M., Celep, F., in press: A new endangered species of Salvia (Lamiaceae) from Turkey. Nordic Journal of Botany.

KaYA, A., Dirmenci, T., 2008: Nutlet surface micromorphology of the genus Nepeta L., (Lamiaceae) in Turkey. Turkish Journal of Botany 32, 103-112. 
LUFT, J. H., 1961: Improvements in epoxy resin embedding methods. Journal of Biophysical and Biochemical Cytology 9, 409.

Marin, P. D., PetKović, B. P., Duletić, S., 1994: Nutlet sculpturing of selected Teucrium species (Lamiaceae): A character of taxonomic significance. Plant Systematics and Evolution 192, 199-214.

Marin, P. D., Duletić, S., Petković, B., 1996: Nutlet ornamentation in selected Salvia L. species (Lamiaceae). Flora Mediterranea 6, 203-211.

Moon, H. K., Hong, S. P., 2006: Nutlet morphology and anatomy of the genus Lycopus (Lamiaceae. Mentheae). Journal of Plant Research 119, 633-644.

Mosquero, M. A. M., JuAn, R., PAstor, J. E., 2002: Morphological and anatomical studies on nutlets of Nepeta L. (Lamiaceae) from South-West Spain. Acta Botanica Malacitana 27, 15-26.

OrAn, S. A., 1997: Nutlet anatomy of the genus Salvia L. in Jordan. Flora Mediterranea 7, 27-40.

Özkan, M., Aktaț, K., Özdemir, C., Guerin, G., 2009: Nutlet morphology and its taxonomic utility in Salvia (Lamiaceae: Mentheae) from Turkey. Acta Botanica Croatica $68,105-115$.

ReJDALI, M., 1990: Seed morphology and taxonomy of the North African species of Sideritis L. (Lamiaceae). Botanical Journal of the Linnean Society 103, 317-324.

RYDING, O., 1992: The distribution and evolution of myxocarpy in Lamiaceae. In: HARLEY, R. M. and REYNOLDS, T. (eds.), Advances in Labiate science, 85-97. The Royal Botanical Garden, Kew.

Ryding, O., 1995: Pericarp structure and phylogeny of Lamiaceae-Verbenaceae complex. Plant Systematics and Evolution 198, 101-141.

Ryding, O., 2001: Myxocarpy in the Nepetoideae (Lamiaceae) with notes on myxodiaspory in general. Systematics and Geography of Plants 71, 503-514.

Ryding, O., 2010: Pericarp structure and phylogeny of tribe Mentheae (Lamiaceae). Plant Systematics and Evolution 285, 165-175.

SALMAKI, Y., ZARRE, S., JAMZAD, Z., 2008: Nutlet micromorphology and its systematic implication in Stachys L. (Lamiaceae) in Iran. Feddes Repertorium 119, 607-621.

SAto, J. E., 1967: A modified method for lead staining of thin sections. Journa of Electron Microscopy 16, 133.

STEARN, W. T., 1992: Botanical Latin, London.

STEMPAK, J. G., WARD, W. P., 1964: An improved staining method for electron microscopy. Journal Cell Biology 22, 697.

SWARBRICK, J. T., 1971: External mucilage production by seeds of British plants. Botanical Journal of the Linnean Society 64, 157-162.

Turner, B. L., Delprete, P. G., 1996: Nutlet sculpturing in Scutellaria sect. Resinosa (Lamiaceae) and its taxonomic utility. Plant Systematics and Evolution 199, 109-120.

Wagner, S., 1914: Contribution à l'étude anatomique du fruit des labiées. Université de Paris, Lons Le-Saunier.

Walker, J. B., Sytsma, K. J., Treutlein, J., Wink, M., 2004: Salvia (Lamiaceae) is not monophletic: Implications for the systematics, radiation, and ecological specializations of Salvia and tribe Mentheae. American Journal of Botany 91, 1115-1125. 
Walker, J. B., Sytsma, K. J., 2007: Staminal evolution in the genus Salvia (Lamiaceae): Molecular phylogenetic evidence for multiple origins of the staminal lever. Annals of Botany 100, 375-391.

WitzTum, A., 1978: Mucilaginous plate cells in the nutlet epidermis of Coleus blumei Benth. (Labiatae). Botanical Gazette 139, 430-435.

WoJCIECHOWSKA, B., 1958: Taxonomy, morphology and anatomy of seeds in the genus Salvia L. (In Polish). Monographie Botanicae 6, 1-56.

WojciechowsKA, B., 1961: Fruits in the middle European species of some genera of Stachyoideae (fam. Labiatae). Monographie Botanicae 12, 89-120.

WojcIECHOwskA, B., 1966: Morphology and anatomy of fruits and seeds in the family Labiatae with particular respect to medicinal species. Monographie Botanicae 21, 119-243.

WojciechowsKA, B., 1972: Morphology and anatomy of fruits of Scutellaria, Chaiturus, Galeobdolon and Sideritis of the family Labiatae. Monographie Botanicae 37, 137-168.

Zhou, S. L., PAN, K. Y., Hong, D. Y., 1997: Pollen and nutlet morphology in Mosla (Labiatae) and their systematic value. Israel Journal of Plant Sciences 45, 343-350. 